\title{
O CORPO NO INFERNO
}

\author{
Sergio Rizo ${ }^{1}$ \\ sergiorizo@sergiorizo.com
}

\section{O CORPO E O COSMO}

Na Comédia de Dante, a descida em forma de espiral em direção ao corpo do Demônio conforma o princípio arquitetônico do Inferno. Sendo um lugar de figurações simbólicas, sua geometria organiza, racionalmente, um complexo geográfico de punições compartimentadas, os precipícios e as valas, segundo um desenho de curvas concêntricas que culminam em Satã. Trata-se de um enorme e incomensurável buraco aberto na terra. No seu ensaio sobre o Inferno de Dante, Flávio Aguiar diz:

O principio estrutural do Inferno é a descida ao horror (este é o efeito do seu formato cônico); seu principio formal é o da irrupção de um tempo em outro tempo. As almas que purgam suas penas no Inferno são visionárias, podendo ver o futuro e o passado. São cegas para o presente, mas ávidas de presença; ávidas perante essa oportunidade única que o poeta lhes oferece em sua eternidade muda. Através do olhar e da palavra do poeta elas têm a oportunidade de aceder à palavra humana, à história. No Inferno o tempo histórico, de desejo, paixão e queda, irrompe na ordem eterna do Juízo Final. (NOVAES, 1997, p. 322)

A convergência do traçado espiralado do buraco e o curso descendente dos quatro rios infernais, leva ao poço congelado do Cócito, onde se encontra o corpo demoníaco, a visão final e o limite do Inferno. Dante se confronta com a visão terrível do corpo de Satã e, neste ponto, prossegue Aguiar:

Para sair do Inferno, Dante deve passar pelo corpo de Lúcifer, no vértice do cone que ele descera em companhia de Virgílio. O poeta se apóia nos pêlos de Satã e desce até a virilha do gigante tricéfalo, que masca os três grandes traidores da humanidade: Cássio, Brutus e Judas. Passado esse ponto nevrálgico do mundo, do inferno, e do universo, ponto a que convergem as linhas do subterrâneo em que o poeta se perdera,Dante se dá conta de que não desce mais, mas sobe; voltando à rocha, contempla uma imagem nova

\footnotetext{
${ }^{1}$ Professor da Faculdade de Arquitetura e Urbanismo da Universidade de Brasília (FAU-UnB).
} 
do mundo satânico: o Mal personificado, Lúcifer, senhor do mundo subterrâneo e contendor dos desígnios divinos no terreno, está de pernas para o ar, como fora jogado do céu depois de sua revolta contra Deus. (NOVAES, 1997, p. 317)

Há um paralelo da posição invertida do corpo do Demônio no Inferno, que é a mesma em que se encontram as almas danadas no canto XIX (trata-se dos simoníacos e seu pecado é o da fraude simples), que têm a pena de serem metidos de cabeça para baixo em estreitos buracos redondos, só com a perna para fora e com fogo ardendo na planta dos pés.

O corpo de Lúcifer ao cair, sofre a ação da força gravitacional terrestre, dramaticamente investido de uma pesada materialidade carnal, função do seu gigantismo outrora celeste. Lúcifer, antes da queda, habitava a esfera divina ao lado de Deus, sendo o mais belo entre os anjos e um espírito superior com o atributo da leveza etérea. Gravidade significa atração para baixo, a região inferus, e o corpo enorme de Lúcifer abre uma gigantesca cratera ao chocar-se com o solo."O peso do corpo, foi associado à decadência pela tradição cristã”. (FERRO, 1981, p. 78)

$\mathrm{Na}$ medida em que se aprofunda nas entranhas da terra, cada vez mais para baixo, mais ele se torna concreto, numa progressiva e intensa materialização terrena. Sua nova aparência encarnada fica sujeita, desde então, às leis que regem o mundo dos homens. Ora, após a terrível queda e sob medonha forma, a de Satã, o demônio medieval, é de se esperar que ele tenha ficado severamente arranhado com raspas da terra entranhadas no seu corpo peludo. E que o seu corpo tenha deixado restos incrustados nas pedras durante a queda. $\mathrm{O}$ contato íntimo dessas substâncias, a pele, a carne, a rocha, a terra, indica uma relação metafórica e histórica entre o corpo e o mundo, análoga ao simbolismo gnosticista, cristão e platônico do locus terrenus. Segundo a interpretação gnóstica, a existência terrena é uma região de exílios sombrios, tenebrosos e, para Paracelso, o lugar para onde Lúcifer foi expulso: o próprio Inferno.

O gnosticismo, ou movimento da gnose (conhecimento), deu-se entre o século I a.C. e o século IV d.C., e seus antecedentes eram relacionados às religiões mesopotâmicas, com raízes no pitagorismo e no platonismo. O apogeu da gnose se deu no século II, coincidentemente com o esplendor ecumênico da Igreja. A gnose, também chamada de Corpus Hermeticum, era uma religião própria, embora muitas vezes difícil de diferenciar da filosofia grega e do cristianismo. Suas principais características diferenciadoras, tanto da tradição grega quanto da cristã, eram a depreciação do cosmos 
e a rejeição da reconciliação divina com os pecadores. Além disso, a revelação gnóstica se distingue do racionalismo grego porque ela não pode ser adquirida pela razão, e da revelação do cristianismo, por não ser enraizada na história e de não ser transmitida pela Escritura. A revelação da gnose é, antes de tudo, uma intuição dos mistérios do Ser. Este mundo, estranho a Deus, e feito da matéria do mal e possuído por demônios maléficos, é concebido como uma ilusão, ou uma anomalia, dominado por Javé, um demiurgo judeu, cuja criação e história são depreciadas.

As diversas correntes místicas ${ }^{2}$ que formaram o cerne da crença gnóstica acreditavam num dualismo zoroastriano e platônico. A jornada em busca da perfeição original, que antecedeu a própria criação do mundo, consistia em sair do kenoma, o vazio material do mundo das manifestações terrenas, e atingir a plenitude espiritual do mundo de luz divino, o chamado pleroma. A criação do mundo, na visão gnóstica, era um gesto de imperfeição, corrupto e medonho. A chave para a ascensão espiritual gnóstica era o conhecimento das práticas de magia astral. Por intermédio desse conhecimento transpunham-se, progressivamente, os estados brutos da matéria, a começar pelo chumbo, o mais grosseiro, ou ainda, a veste imunda da alma, que correspondia ao planeta Saturno. A cada estado da matéria, correspondia um planeta. As fases seguintes eram: Júpiter-estanho, Marte-ferro, Vênus-cobre, Mercúrio-mercúrio, Lua-prata e Sol-ouro, o último estágio, sendo o ouro o símbolo da perfeição absoluta. Os metais representavam a matéria enferma que depurada, atingia a sua perfeição no ouro. E cada planeta tinha um portão guardado por um demônio planetário, e a passagem por eles exigia a chave para abrir os selos, que era a prática ritualística e o conhecimento da gnose. Foi em termos da tradição cristã, cuja natureza sincrética reeditou com êxito os ritos mistéricos, que se deu a emergência da gnose, pretendente da investigação da queda do homem, da precariedade da sua existência histórica e da sua salvação.

Os sistemas mitológicos do cristianismo e da gnose fundiram concepções religiosas que em alguns aspectos muito se assemelhavam, como o desprezo pelo corpo terreno, e em outros divergiam consideravelmente, como na questão do pecado original. E não poderia ter sido diferente, pois os mitos não têm seu ponto de partida em nenhum

\footnotetext{
${ }^{2}$ De acordo com Aby Warburg (1866-1929), historiador alemão, foram nos primeiros séculos da era cristã que convergiram linhas de todas as disciplinas que formam o complexo da filosofia hermética: a alquimia, a magia astral e a cabala. Esta convergência teve lugar em Alexandria, o antigo centro da cultura universalista grega em solo egípcio, constituída por um amálgama de povos de várias raças, como colonos gregos e romanos, egípcios e judeus.
} 
conceito conclusivo do eu ou da alma, nem tão pouco em nenhuma imagem conclusiva da realidade e do acontecer. Mitos têm que criá-los a partir de si mesmos, segundo Schelling.6 A concepção do corpo e da alma no gnosticismo envolve uma tríplice representação mística composta pelo aspecto hilogênico, ou o corpo, o psíquico, ou a alma, e o pneumático, ou o espírito. No cristianismo, especialmente em São Tomás de Aquino, esta mesma representação se reduz à ordem do binário, ou seja, do corpo e da alma.

No mito da queda do homem, o paralelo entre a versão cristã e o da gnose se dá conforme explica Cousté: ${ }^{3}$

Se para o cristão a queda é uma conseqüência do pecado, para o gnóstico, em troca, ela é anterior a este último, de modo que o pecado constitui uma conseqüência lógica da queda. Mas não sua causa, sem dúvida. Em um caso é o homem, ser criado puro, quem ao pecar se macula e determina a queda; no outro, o próprio homem é uma parte integrante da queda. Só peca em seguida, e porque pertence à categoria dos espíritos decaídos. Para o cristão, a salvação coincidirá com a ressurreição do corpo restaurado em seu estado „glorioso" anterior a falta original. (COUSTÉ, 1996, p. 183)

No gnosticismo, então, a condição eterna e amaldiçoada do corpo, como prisão da alma, é patente e pertence ao domínio da matéria. Portanto, o pecado é inerente ao seu estado de espírito decaído, e da matéria corrompida que será levada à destruição, enquanto a alma pneumática será reintegrada ao alto do mundo.

O Demônio, na gnose, figurava não só como um símbolo ativo do mal, mas também como a potência que trouxe o conhecimento. Tanto é que existia uma seita, a dos ofitas, que adorava a serpente por ter levado o conhecimento ao Paraíso. A versão do mal no arconte Diabo da gnose, é tão poderosa quanto Deus (o Pai trinitário), sendo capaz de conceber um filho terreno, um Cristo Negro. Esta figuração advém da concepção cabalística ${ }^{4}$ e alquimista dos dois Adãos; os restos do Adão-Kadmon ou homem primordial haviam produzido o seu mentor Adão-Belial, que para a Igreja era o Diabo. Mas para uma parte da gnose, ele era o princípio da inteligência e do livre-

\footnotetext{
${ }^{3}$ Friedrich Schelling foi um filósofo alemão, no período do romantismo, 1775-1854. Escreveu sobre a metafísica subjetiva, condenada a repetir a infindável tautologia $\mathrm{Eu}=\mathrm{Eu}$.

${ }^{4}$ Cabala, ou Kabbalah, significa literalmente "tradição". Num sentido mais amplo, é o corpo da doutrina esotérica do judaísmo que teve origem no início da era cristã. Como designação do misticismo judaico, data do século XIII. Compõe-se de um tratado filosófico-religioso hebraico, com a decifração de um sentido secreto da Bíblia e uma teoria e um simbolismo das letras e dos números (chamado de Sefirot).
} 
arbítrio dos homens. É justamente este caráter prometéico do Demônio que Cousté enfatiza no seu livro Biografia do Diabo.

As representações literárias e as imagens da metáfora corpo-terra, estruturadas simbolicamente em torno da relação do macrocosmo-mundo e do microcosmo-homem, que na idade média tiveram uma existência marginal, ganham impulso no Renascimento com as obras da tradição alexandrina traduzidas por Marsílio Ficino. Figura central da academia platônica florentina, ele traduziu uma coletânea de catorze tratados gnósticoneoplatônicos, dos primeiros tempos do cristianismo, compilação também conhecida pelo título de Corpus Hermeticum. Nas imagens que relacionavam o homemmicrocosmo aos planetas-macrocosmo, perdurava a astrologia, conhecimento que continuou através da Idade Média cristã, que, impotente de suprimi-la, acabou por assimilá-la.

A medicina e as ciências naturais medievais estavam particularmente impregnadas de elementos de astrologia. A fé não negou nem eliminou tais elementos, mas os subordinou ao poder da Providência Divina. E foi graças a tal subordinação, que a "astrologia pode continuar incólume como princípio do conhecimento do mundo". (CASSIRER, 2001, p.166)

A visão medieval cristã do cosmos enfatizava a hierarquia espacial, valorizando o "em cima" e desprezando o "embaixo", estabelecendo um movimento vertical ordenador da ascensão celeste em direção a Deus. Tomava o motivo do que está além deste mundo num sentido ao mesmo tempo espacial e espiritual, como aspectos indissoluvelmente amalgamados. O pensamento medieval era de que os corpos celestes descreviam órbitas circulares perfeitas ao redor do centro do mundo. A Terra, enquanto criação divina, centralizava a regência ordenada do movimento dos astros, segundo o modelo cosmológico de Ptolomeu, que vigorou até a revolução proposta pelo sistema heliocêntrico de Copérnico, no século XVI. Na Divina Comédia de Dante, por exemplo, a alma, na sua peregrinação, ascende do reino dos Infernos, cuja forma cônica se projeta no interior da terra, através da Montanha da Purificação (purgatório) e das nove esferas dos planetas, das estrelas e da esfera de cristal, todos eles mantidos em movimento pelos anjos, até chegar ao Paraíso, onde encontra o seu refúgio na rosa branca celeste, iluminada pela luz divina.

Foi somente a partir do século XVI, no Renascimento, que a cosmologia incorporou um novo sistema de representações, em que o homem era centralmente figurado como um microcosmo relacionado ao macrocosmo dos astros celestes. "Já que 
nenhum método nos está à mostra para atingir as coisas divinas à não ser por símbolos" (CASSIRER, 2001, p.90), dizia Nicolau de Cusa ${ }^{5}$, asserção bastante significativa numa época em que a representação do corpo humano passou a ser vinculada aos símbolos do zodíaco. Na doutrina de Nicolau, que enfatizava o singular e o individual, só se podia chegar a Deus pelo conhecimento (gnose). E conhecer significava ler a escrita divina na natureza. E então ver "a natureza da relação fundamental que existe entre Deus, o ser que tudo abarca, o ser do infinito, e a singularidade última; cada ser singular e individual está numa relação direta com Deus" (CASSIRER, 2001, p.54). Como exemplo, tem-se o diagrama das correlações entre o micro e o macrocosmos de Athanasius Kircher, que remete para as teorias da correspondência na tradição platônica e hermética. Trata-se de uma gravura constante da sua obra Mundus subterreanus, de 1682, em que o mundo é descrito como um organismo vivo com processos metabólicos. A representação mostra o corpo de um homem, aberto da região do peito até a virilha, em que aparecem seus órgãos internos. Na sua obra Musurgia universalis, Kircher faz corresponder o sol ao coração, a lua ao cérebro, Júpiter ao fígado, Saturno ao baço, Vênus aos rins, Mercúrio aos pulmões e a Terra ao estômago. Nela ele diz que as veias são os rios, e a bexiga o mar. Os sete membros principais são os sete corpos metálicos, as pernas as pedreiras, a carne a terra, o cabelo a erva. Kircher dá expressão própria às alegorias éticas de Giordano Bruno, que tentavam elucidar as relações do mundo interior através de imagens do cosmo visível. Segundo Cassirer, "as forças que movem o interior do homem são vistas como potências cósmicas, as virtudes e os vícios como constelações”. (CASSIRER, 2001, p.126)

O Renascimento era, com suas forças espirituais e produtivas, voltado para o aprofundamento do indivíduo, o que possibilitou a maturação de uma consciência de si mesmo, própria do homem moderno. E um sentimento de valor individual pela sua vinculação simbólica aos fenômenos cósmicos da natureza, e pelas metáforas de um mimetismo antropomórfico ou teomórfico; "o mundo é a imagem do homem - é o universo-corpo, o universo-habitat. O mundo é a imagem de Deus, infinito e todopoderoso, dotado de capacidade criativa”. (DUBOIS, 1995, p.83)

O sistema concebido por Pico Della Mirándola ${ }^{6}$, por exemplo, girava em torno de três elementos: Deus, universo e homem. Deus é o Ser definido pela Bíblia. O universo compreende o mundo intelectual (de Deus e dos anjos), o mundo celeste (as dez esferas celestes, das quais a última, empíreo, é a fonte do movimento) e o mundo

\footnotetext{
${ }^{5}$ Nicolau de Cusa, teólogo alemão, nascido em 1401 e falecido em 1464. Como filósofo, elaborou o conceito da coincidência dos contrários. Antecipou a teoria do sistema copernicano.

${ }^{6}$ Filósofo italiano, nascido em Mirandola em 1463, e falecido em Florença em 1493.
} 
elementar ou sublunar (dos Seres terrestres). O homem é um microcosmo, um mundo integral que, numa síntese de alma, espírito e corpo, possui elementos das outras ordens. Por um outro lado, no seu aspecto negativo, a imagem do universo podia ser caótica, plena de ruído e fúria, uma conformação demoníaca dos espíritos da terra e do inferno, onde os demônios são mensageiros de um outro mundo, localizado abaixo da terra ou nas trevas.

Um outro exemplo de correspondência simbólica diz respeito ao espírito de investigação dos fenômenos da natureza de Leonardo Da Vinci, que fez no seu Tratado da Pintura uma comparação entre o corpo do homem e a terra:

Os antigos chamavam o homem de mundo menor, denominação justa, pois ele está composto de terra, de água, de ar e de fogo, como a matéria terrestre, a qual se assemelha. Se o homem tem ossos que lhe servem de armação e sustentação da carne, o mundo tem também rochas que sustentam a terra; se o homem leva consigo um lago de sangue onde infla e desinfla o pulmão quando respira, o corpo da terra tem também seu oceano, que cresce e decresce a cada seis horas para sua respiração; se desse lago de sangue partem veias que vão ramificando-se por todo o organismo, também o mar oceano enche os corpos terrestres de inumeráveis veios de água; mas faltam nervos ao nosso globo que não lhe foram concedidos por que são eles que ocasionam o movimento. No entanto, o mundo, em perpétua estabilidade, não se move, e onde não há movimento, os nervos são inúteis, mas no restante, homem e mundo são iguais. (Da VINCI, 1950, p.198)

\section{AS METÁFORAS DO CORPO}

Todas essas menções feitas ao corpo humano indicam o seu fator físico e orgânico como o principal parâmetro histórico nas comparações e metáforas, tanto gnósticas quanto cristãs, com os fenômenos da natureza, do mundo e do cosmo. O corpo do homem passa progressivamente a ser o símbolo por excelência da natureza terrena e da sua correspondência astral. A insistência no corpo, como a medida das coisas, externas e internas, como exemplar na ciência da proporção e como mapa do funcionamento dos órgãos na medicina, parece remeter a obsessão cristã com a carne. E tal fato não deixa de ser curioso, visto o privilégio que a ideologia cristã dispensa a alma. Jean Claude-Scmitt, no seu ensaio Corpo e Alma (SCMITT, 2002, p. 265), explica que "O corpo oferece o modelo concreto de uma organização hierárquica do real que 
ultrapassa muito a simples observação da pessoa humana e abre caminho a uma floração ilimitada de metáforas".

Ele discorre ainda sobre essa questão dizendo que a Igreja, desde as suas origens, "pensou-se simbolicamente como um „,corpo “ (segundo a onipresente metáfora paulina do corpo e dos membros) reunido pela celebração eucarística (1 Coríntios 11, 33)”. (SCMITT, 2002, p. 265)

A Igreja atribuía ao corpo um duplo sentido simbólico: por um lado, diga-se idealizado, tinha-se o corpo canônico, símbolo do corpo da Igreja, que resultava nas representações do Corpo Místico de Cristo; por outro, o lado real e sensível, a carne representava o aspecto frágil da condição humana. Para São Cipriano, por exemplo, a preservação da integridade do corpo era um assunto da maior importância para a doutrina cristã, pois ela representava "A fraqueza do barro mortal". (BROWN, 1988, p. 194)

A carne marcava, para Cipriano, "um ponto de perigo perpétuo, um posto avançado do „self “, propenso a receber uma miríade de golpes do mundo”. (BROWN, 1988, p. 194) Apesar de fraco nele e dele, e notoriamente exposto à tentação sexual, o corpo era menos assediado pelo „fogo " escondido da sexualidade no seu interior do que pelo perigo de ser envolvido, no seu exterior, na sinistra força atrativa do mundo. Nos escritos de Cipriano, o corpo do cristão emergia como o microcosmo do ameaçado estado da Igreja, que por sua vez era um corpo compacto, firmemente retido pela vontade inabalável, vinda de Deus, da sua cabeça e da sua mente orientadora, o Bispo. Como um grande organismo, era para a Igreja rejeitar, com uma „,intolerância visceral ", a ameaça letal do sacrifício pagão.

O corpo do cristão era sitiado não somente pela sensualidade "mas pelas mais pesadas e devastadoras luxúrias mundanas do ódio, do ciúme e do orgulho eclesiástico". (BROWN, 1988, p. 194)

"Porque a alma é forma e é ela que faz o corpo" (CLARK, 1956, p. 23). Esta citação tirada do Hymne in Honour of Beautie de Spencer, é emblemática da relação sempre paradoxal entre o corpo e a alma, existente nas formulações de textos e de imagens do cristianismo.

O corpo, enquanto objeto da tentação e instrumento do pecado, é a justificativa terrena da existência do inferno. A alma é a justificativa do Além. A metáfora que exprime a dualidade cristã do corpo é a do carcer terreno, a prisão terrestre da alma 
imortal. Em termos das imagens religiosas, cabe aqui uma observação: a dualidade do corpo e da alma estruturou um interessante paradoxo nas representações da arte cristã do céu e do inferno. Nas pinturas e esculturas, a alma etérea assumiu quase sempre a materialidade do corpo físico, a ponto de indicar a possibilidade da categoria do corpo alma. É o corpo que possibilita a alma a sua referência espacial e a sua substância física, pois "são múltiplos os espaços da alma, e as suas regiões, os seus compartimentos: e o corpo é o que multiplica a alma, lhe oferece uma geografia, uma geologia, uma tipologia". (GIL, 1997, p. 156)

No maniqueísmo ${ }^{7}$, religião entranhada no sistema gnóstico e que comungava com o cristianismo o mesmo desprezo pela carne, o corpo comum era uma causa perdida. O conceito da carne detestável era aplicado a todos os corpos dos homens, com a exceção dos eleitos, crentes nesse sistema religioso. Para os gnósticos, a representação do corpo transforma-se numa espécie de tabela referencial e simbólica das influências sobre ele exercidas pelas forças astrais. Na concepção da gnose, a alma cósmica que habitava no domínio dos astros, reflexo das ideias da esfera superior e transcendente do intelecto divino, podia corresponder com a estrutura tripartida (corpo, alma e espírito) do pequeno universo do homem (microcosmo), a esfera inferior, material e transitória. O homem tinha então a possibilidade de manipular eventos na esfera terrena, recorrendo a práticas mágicas e alquímicas como seja a preparação de talismãs, de exorcismos ou esconjuros, de modo a afetar a esfera intermediária da alma cósmica.

O homem, tanto na concepção gnóstica quanto na cristã, foi criado por Deus a partir da matéria da terra. Na versão da gnose o mito da Criação do Homem se dá conforme a seguir:

Quando o homem pecou, Deus ficou irado $e$ amaldiçoou a terra vermelha (Adão deriva do hebreu Adamah, „terra vermelha", interpretado como uma referência ao vermelho do lapis $^{8}$ ), destruiu as suas proporções intrínsecas, transformou a homogeneidade em heterogeneidade e operou essa mudança pondo os elementos numa fusão ofensiva das matérias, de que resultou a corrupção e a morte. (ROOB, 2001, p. 165)

\footnotetext{
${ }^{7}$ Doutrina fundada por Mani, no século III, na Pérsia, que acreditava num universo regido por dois princípios opostos e rivais, o bem absoluto ou Deus, e o mal absoluto ou Diabo. Segundo Alberto Cousté, no seu livro Biografia do Diabo, p. 123, “o maniqueísmo é a única seita independente surgida diretamente da tradição cristã"

${ }^{8}$ Tipo de pedra vermelha, em latim.
} 
Na versão cristã, diz a Bíblia: "Formou pois o Senhor Deus ao homem do limo da terra, e assoprou sobre o seu rosto um assopro de vida; e recebeu o homem alma e vida" (GÊNESIS 2,7). Esses elementos mencionados nos mitos de criação estão relacionados à matéria da terra. A pedra vermelha, o limo, e em outras versões bíblicas, o pó da terra, a lama, o lodo e o barro, são todas substâncias constituintes do solo terrestre. $\mathrm{O}$ fato de que o homem primordial foi feito da mesma substância da terra deu margem ao estabelecimento de metáforas que faziam corresponder o corpo aos elementos do mundo e da natureza. As metáforas corporais faziam do mundo um "macro-antropos", ou do homem um "microcosmo". Simbolicamente, a terra opõe-se ao céu como a obscuridade à luz; a densidade, a fixação e a condensação à natureza sutil, volátil, à dissolução.

A terra simboliza ainda a função maternal: “Tellus Mater. Dá e rouba a vida. Prostrando-se sobre o solo, Jó exclama: Nu saí do seio materno, nu para lá retornarei (I, 21), identificando a terra-mãe com o colo materno" (CHEVALIER, 1998, p.879). Uma correspondência simbólica bastante interessante é a que relaciona a geografia da terra com a consciência humana, feita pelo psicólogo francês Paul Diel (1893-1972) que:

(...) esboçou toda uma psicogeografia dos símbolos, em que a superfície plana da terra representa o homem como ser consciente; o mundo subterrâneo, com seus demônios e seus monstros ou divindades malevolentes, figura o subconsciente; os cumes mais elevados, mais próximos do céu, são a imagem do supraconsciente. Toda a terra se torna, assim, símbolo do consciente e de sua situação de conflito, símbolo do desejoterrestre e de suas possibilidades de sublimação e de perversão. É a arena dos conflitos da consciência no ser humano. (CHEVALIER, 1998, p.880)

A terra também oferece fértil campo para as metáforas de enormes criaturas, como a que fez Goethe quando disse imaginar "a terra com o seu círculo de vapor semelhante a uma enorme criatura viva, que constantemente inspira e expira." (ROOB, 2001, p. 179)

Ao imaginar esse gigantesco corpo da terra, Goethe deu seguimento à tradição hermético-platônica, de considerar os planetas como criaturas físicas com uma pulsação interior, um coração de fogo na região central de onde partia a rede venosa dos canais de lava subterrânea, e uma circulação aquosa, por meio da qual a água do mar chegava 
às grandes montanhas através de imensos tanques subterrâneos, dos quais refluia em seguida dos rios para o mar.

Uma outra ordem de metáforas corporais se vinculou ao pensamento de Kepler' ${ }^{9}$, que fez referência à alma do mundo no seu comentário sobre o interior da terra grávida:

Vi reforçada a minha opinião de conferir uma alma a terra (...), pois deve haver uma força modeladora nas entranhas da terra que, à semelhança de uma mulher prenhe, imprime na rocha frágil os eventos da história da humanidade, tal como se desenrolaram na superficie(..) (ROOB, 2001, 179)

O interior da terra, como um grande organismo, serviu para diversas metáforas corporais feitas por Athanasius Kircher. Ele nasceu na Alemanha em 1601 e faleceu em Roma em 1680, tendo sido um sábio jesuíta com notável conhecimento enciclopédico e estudioso das ciências naturais, língua clássica, hieróglifos egípcios, alquimia, astrologia, além de colecionar todos os tipos de antiguidades e vestígios etnológicos. Destacou-se, também, como explorador de vulcões, tendo pesquisado o Etna e o Vesúvio. Como investigador das forças subterrâneas, publicou a sua grande obra Mundus Subterraneus em 2 volumes na cidade de Amsterdam no ano de 1678. Durante décadas, Kircher esteve radicado em Roma, no centro de informações da missão dos Jesuítas, o que lhe permitiu recolher dados e material proveniente das partes mais remotas do mundo para a sua coleção e para os seus escritos.

Numa das obras de Athanasius Kircher, a Musurgia Universalis, existe um diagrama das correlações entre o micro e o macrocosmo, em que ele remete para as teorias das correspondências na tradição platônica e hermética. Nelas, o mundo é descrito como um organismo vivo com processos metabólicos. A correspondência que aqui nos interessa, além da dos astros superiores, é a da própria Terra com o corpo humano. Ela estabelece a relação da Terra com o estômago, onde as veias são os rios e a bexiga, o mar. Os sete membros principais são os sete corpos metálicos, as pernas as pedreiras, a carne a terra e o cabelo a erva.

Esse sistema de representação simbólica não era novidade na época, pois já desde a Renascença, existiam diversas traduções dos documentos originais do platonismo. Um exemplo apropriado foi obra de Marcilio Ficino (1433 - 1499), filósofo platônico atuante na corte dos Médici, em Florença. Ele se propôs a tarefa tripla de

\footnotetext{
${ }^{9}$ Johannes Kepler, alemão, nascido em 1571 e falecido em 1630, físico, matemático e astrônomo.
} 
traduzir os "Platonici" (Plotino, o Pseudo - Dionísio, o Aeropagita, "Hermes Trimegistro",etc), sistematizar esses escritos de forma a moldar uma nova significação da herança cultural da época (de Virgilio, de Santo Agostinho,de Dante, da mitologia clássica e da física), e harmonizar esse sistema com a religião cristã.

Existe também uma outra categoria de correspondências simbólicas do corpo, enquanto possuidor de um temperamento típico, que se define pela sua relação com os quatro elementos materiais: a água, o ar, o fogo e a terra ${ }^{10}$. Essa categoria relaciona assim os elementos aos temperamentos: a água ao linfático, a terra ao bilioso, o ar ao sangüíneo e o fogo ao nervoso. O conceito histórico de temperamento, remonta a época de Hipócrates. Encontra também em Galeno um outro expoente da medicina que adotou este princípio na sua terapêutica. Como norma do pensamento médico instituiu-se, predominantemente, até o século XVII, propondo-se explicar os vários aspectos da fisiologia e da patologia de cada ser humano, incluindo sua constituição e temperamento. Isto era feito segundo as diferentes proporções dos quatro humores orgânicos tidos como fundamentais: o sangue, a bílis comum, a mítica bílis negra, ou atrabílis, e o viscoso fleugma (hoje liquido linfático). Essas relações eram ainda caracterizadas pelas quatro qualidades essenciais: frio/quente, seco/úmido, leve/pesado e fixo/volátil. A saúde dependia do justo equilíbrio dos humores, que por sua vez eram balizados por uma teoria das proporções dos elementos. A classificação do caráter se dava segundo o predomínio de um dos humores, linfa: fleumático; bile negra: melancólico; bile amarela: fantasista; sangue: colérico. Os estados patológicos da apatia, melancolia negra, sonhos, fantasias, cóleras e impulsos, eram devido ao desequilíbrio ou excesso de um dos humores.

Esse sistema diferia da classificação da personalidade do homem de base morfológico-astral, pois enquanto esta visava ao reconhecimento de alguns tipos humanos fundamentais com base no caráter e no aspecto externo, o temperamento se dispunha a penetrar nos segredos do organismo humano.

Depois que as opiniões dos gnósticos se tornaram conhecidas no século XVI, nos extensos excertos de seu ensino, constantes nas edições de trabalhos de seus oponentes, tanto católicos como protestantes, as suas ideias tiveram uma profunda influência nos idealistas, como Goethe e Hegel. O movimento teosófico do século XX considera o gnosticismo como o seu ancestral espiritual, com ele compartilhando muitas

\footnotetext{
${ }^{10}$ Para os gregos, bem como para a maioria das tradições, são estes os quatro elementos, que, vale lembrar, não são de modo algum irredutíveis entre si; ao contrário, transformam-se uns nos outros.
} 
características comuns. A própria psicologia Jungiana muito deve a este movimento, tendo em vista suas interpretações das experiências religiosas da mitologia gnóstica. $\mathrm{O}$ gnosticismo moderno, entretanto, é monista, enquanto o gnosticismo antigo era essencialmente dualista. A atualidade do gnosticismo, na sua crença de que o Inferno é aqui mesmo, na terra, na realidade do cotidiano, coincide com o que Ítalo Calvino escreveu, em 1972, no final das Cidades Invisíveis:

O inferno dos vivos não é coisa que está para chegar; se existe um inferno, é aquele que já temos, que habitamos todos os dias e nele estamos todos juntos. Existem duas formas de não sofrer. A primeira é facilmente conseguida pela maioria: aceitar o inferno. Tornar-se parte dele a ponto de o não ver. A segunda é arriscada e exige atenção e aprendizagem contínuas: procurar e saber reconhecer quem e o quê, no meio do inferno, não é o inferno, e faze-lo durar e oferecer o seu lugar. (CALVINO, 1972)

No tocante as metáforas corporais relativas ao Inferno, o grande místico do século XVIII, Emanuel Swedenborg, fez duas menções características da sua forma: "Deus proíbe aos homens e aos anjos traçar um mapa do inferno, mas sabemos que sua forma geral é a de um demônio”. (BORGES, 1996, p. 147) Em 1758, Emanuel Swedenborg escreveu: "Não me foi concedido ver a forma geral do Inferno, mas me disseram que, do mesmo modo que o Céu tem forma humana, o Inferno tem a forma de um demônio". (BORGES, 1996, p.111)

$\mathrm{Na}$ atualidade, as noções do corpo e da alma ficam problematizadas pelas confluências, muitas vezes contraditórias, dos aspectos científicos e culturais que intermediam a sua relação, como a medicina, que categoriza a alma como o cérebro, de capacidade física e funcional limitada ao organismo humano (neurologia); a psicologia, que trata da manifestação emocional da mente; da filosofia, que investiga a consciência ou o modo de entendimento de si e do mundo pelo homem; e as diversas e diferentes crenças religiosas, que atribuem uma existência espiritual após a morte. Ou para colocar de outra forma, "na nossa cultura, sujeito é aquele reduto interno, seja psíquico, seja mental, seja espiritual. Na psicologia chamar-se-á psique; nos círculos esotéricos, mente; na filosofia, consciência; nas religiões cristãs, alma ou espírito". (FONTANELLA, 1995, p.10)

As questões do além, em termos teológicos e da liturgia oficial cristã, que anteriormente eram determinantes do modus vivendi das sociedades ocidentais, 
medievais e renascentistas, com todo o aparato de poder da Igreja e do rei, ficaram relegadas ao campo mais restrito das práticas e crenças religiosas, na concepção moderna dos estados democráticos. Ou então encontraram, já desde Dante, um espaço conveniente na literatura e na arte da imaginação. Mas existe um outro aspecto, relativo ao imaginário, entendido como "o resultado visível de uma energia psíquica formalizada individual e coletivamente" (DUBOIS, 1995, p.21), que tem sido o foco de atração de estudos humanísticos a partir da segunda metade do século XX, e que não parece ter deixado de manifestar sua influência histórica na formação das imagens contemporâneas. A bem da verdade, não só no campo da arte e da literatura, mas em todas as atividades humanas, científicas inclusive, a herança do imaginário secular, do medievo e da renascença, deixa de se manifestar. De acordo com a interpretação de Dubois, o imaginário é a teia de sentidos que propicia a construção dos referentes sociais e individuais, com relação aos grandes e perenes temas da humanidade, quais sejam, a natureza, o tempo, o espaço, o homem e a cidade. Talvez seja uma situação do mundo, talvez seja a situação do indivíduo numa sociedade massificada contemporânea, mas seja o que for, está engendrando um grande interesse na literatura da imaginação que apresenta especulações em campos além da nossa existência física diária. A ficção científica é a mais óbvia e popular manifestação desse tipo, com inúmeras publicações anuais no mercado mundial de livros.

Ao se examinar um pouco mais, vê-se que cada ano surgem novos estudos eruditos em livros universitários com o tema das experiências extracorpo no além. Incluem-se aí também, os estudos relativos aos temas do demônio, céu e inferno e misticismo. Os estudiosos estão examinando estes temas e as funções que eles têm como símbolos e arquétipos na psique individual e na sociedade. $\mathrm{O}$ fato é que, destarte todo o avanço tecnológico, da onipresença dos computadores e do conhecimento científico, característicos de uma época pós-industrial, o homem atual não deixa de ter um corpo finito e nem de sofrer a angústia da morte. Muito pelo contrario, a decadência do sistema de normas religiosas que regulava as mentalidades coletivas, medievais e renascentistas, não parece ter encontrado no estado moderno e nem na ciência contemporânea um substituto a sua altura, que se dispusesse a cumprir um papel social e religioso de orientação e conforto espiritual na gestão do além. Daí a proliferação de seitas, crendices, fórmulas mágicas e "trabalhos", que persistem em existir no cotidiano das supostamente esclarecidas sociedades atuais. A psicanálise, elitista pelo acesso e custo financeiro, trabalha no ajuste da mentalidade do homem a sociedade em que ele vive; é incapaz de dar respostas ao que se sucede após a morte. A manifestação de algumas 
das patologias psicológicas, como as psicoses, que podem conformar um duplo no homem, "é sintomática da crise da fé do homem moderno que substituiu a transcendência pela mercadoria". (BRUNEL, 1998, p. 278)

O impulso para saber se existe mesmo um além se relaciona ao sentido que a vida atualmente tem, do ponto de vista existencial. A angústia e a incerteza quanto à continuidade da vida depois da morte é uma das inquietações que envolvem a humanidade neste início do século XXI.

\section{o MÍTICO, o MÍSTICO, o POÉTICO, o CIENTÍFICO E O SURREALISTA}

Muitos são os exemplos existentes na história de metáforas que relacionam o corpo com a paisagem. Selecionei cinco que me pareceram apropriados, quatro deles literários (três vinculados à questão do Inferno), e o último de uma imagem visual. A classificação desse conjunto foi feita segundo as diferenças de sua natureza, e de acordo com uma cronologia linear que espelhasse a continuidade entre eles, o que resultou nos seguintes níveis: o mítico, que mostra o trecho bíblico do Leviatã constante em Jó, o místico, que inclui uma parte da visão medieval do inferno de Tundal, o poético, que expõe um trecho do poema do Inferno de Dante, o científico, que consta de uma descrição da paisagem e do corpo animal por Leonardo da Vinci, e uma imagem surrealista do corpo montanha de André Masson e Georges Bataille. Vale ainda explicar que a relação entre o corpo e a paisagem, nos seus aspectos simbólicos e metafóricos, remonta à questão dos mitos de origem das coisas no mundo. É uma matéria rica e vastíssima. Fato é que, se fossem consideradas somente as imagens mitológicas concernentes às várias culturas formadoras do cristianismo, o estudo resultaria por demais extenso. Minha atenção voltou-se, portanto, aos exemplos cristãos, herdeiros da mitologia greco-romana e do gnosticismo, e que melhor ilustram o tema desse estudo. Esses exemplos foram importantes referências no imaginário fabuloso cristão, e fundamentais na compreensão das imagens religiosas produzidas na idade média e no renascimento, além de persistirem na atualidade, conforme irei demonstrar. $\mathrm{O}$ foco das questões será, naturalmente, a ênfase nos termos associados ao corpo, seja no seu aspecto antropomórfico ou animal, e na sua relação com as paisagens imaginadas.

A imagem da boca do Inferno era muito comum na idade média. Símbolo poderoso, derivado de fontes literárias e pictóricas (representações teatrais inclusive), conformou, principalmente, uma vasta iconografia relativa aos temas do Apocalipse e 
do Juízo Final. As fontes literárias principais vieram da Bíblia, compreendendo a descrição do Leviatã no livro de Jó (40:25 - 41:26), parte da Revelação (Apocalipse de S. João - 20) e uma variedade de outras referências associadas ao Hades grego.

Está escrito em Jó:

Quem descubrirá a superfície do seu vestimento? E quem entrará no meio da sua boca? Quem abrirá as portas do seu rosto? Em rodas dos seus dentes está o terror. O seu corpo é como escudos fundidos, apinhoados de escamas que se apertam. O seu espírito é resplendor do fogo, e os seus olhos como as pestanas da aurora. Da sua boca saem umas lâmpadas como tochas de fogo acesas. Dos seus narizes sai fumo, como o de uma panela incendida e que ferve. O seu hálito faz. incender os carvões, e da sua boca sai chama. No seu pescoço fará acento a fortaleza, e adiante dele vai a fome. Os membros do seu corpo bem unidos entre si: enviara raios contra ele, e não o farão mover para outro lugar.

O seu coração se endurecerá como pedra e se apertará como bigorna de ferreiro. (JÓ 41, 4-6, 9-15) ${ }^{11}$

Na versão da Bíblia ${ }^{12}$ que extraí o trecho acima, o tradutor indica que Leviatã provavelmente designa o crocodilo. O fogo que sai da boca do Leviatã seria, nesta interpretação, uma alusão ao forte borrifo d'água que costuma lançar o crocodilo pela boca e pelas ventas, e cujas gotículas iluminadas pelos raios do sol ficam às vezes brilhantes como se fossem chamas.

Leviatã é o nome hebreu de um monstro mítico associado ao mar. A sua representação oscilou entre as figurações de serpente, crocodilo, dragão e baleia. Leviatã era também a personificação do mar, do caos marítimo que uma vez ameaçou a terra, mas que foi dominado por Javé. Os textos bíblicos deixam claro essa dominação na criação - creatio prima. É o monstro paradigmático e o inimigo de considerável mitologia que se sobrepõe a outros representantes do mal e do caos. Etimologicamente, pode significar "o que se torce" e "o espiralado" ou "circular", ambas possibilidades indicando um conceito original de Leviatã como um ser assemelhado a serpente. Esta seria a origem da iconografia da serpente marinha que circunda o mundo. Mas, outras vezes, Leviatã aparece como nome próprio em alguns textos ugaríticos e bíblicos. Portanto, sua aparência física não pode ser deduzida apenas pela sua etimologia. Sendo assim, o estudo desse monstro exemplifica como um mito do oriente médio pode trasladar

\footnotetext{
${ }^{11}$ As palavras em itálico são minhas.

${ }^{12}$ Bíblia Sagrada, Rio de Janeiro, Edição Barsa, 1965.
} 
de uma cultura para outra, ou mesmo se adaptar numa dada cultura, segundo as mudanças do seu percurso histórico, além de evidenciar a fluidez no desenvolvimento do imaginário mitológico da citada região geográfica.

Leviatã pode estar associado, outrossim, às representações que mostram o Deus egípcio Horus espetando a lança no crocodilo do rio Nilo. Esta poderia ser uma das origens iconográficas do monstro, que confirmaria inclusive a menção inicial do tradutor da versão da Bíblia que utilizei. É bastante frequente no trecho citado o uso dos termos vinculados ao corpo e ao organismo, como por exemplo, rosto, boca, dentes e pescoço. O aspecto antropomórfico das metáforas fica por conta do uso do termo pestana (cada um dos pêlos da orla da pálpebra) na caracterização do monstro Leviatã, se admitido na tendência maior de representar o crocodilo ou a serpente. Os pêlos são uma atribuição típica dos mamíferos, estando o homem entre eles, e não dos répteis. Inicialmente, pensei em incluir também o termo rosto, mas depois de pesquisar seu significado descobri que sua etimologia vem do latim rostro ou rostrum, que vale por bico (com o sinônimo rostro - em português) e focinho. De qualquer maneira, é evidente e necessária também, uma ordem zoomórfica na representação em questão.

A iconografia da boca do inferno teve ainda como fonte os apócrifos e as visões medievais, tendo sido selecionada por um princípio de clareza da imagem literária, a visão de Tundal. Era ele um nobre cavaleiro irlandês, que apesar de bem nascido e treinado, não cuidava da salvação da sua alma. Numa ocasião, ao fazer uma refeição na casa de um amigo que lhe devia três cavalos numa troca que haviam feito, foi acometido de um mal súbito e quedou paralisado, como morto, durante três dias. No quarto dia, quando prestes a ser enterrado, voltou a si, e após restabelecer-se do acontecido, agradeceu a Deus pelo seu retorno, distribuiu seus pertences entre os necessitados e passou a levar uma vida pura, bem diferente da que tinha anteriormente. Mas antes disso acontecer, logo depois que despertou do seu coma, Tundal contou às pessoas que com ele se encontravam o que havia ocorrido na sua jornada no Além. Logo após ter-se dado conta da sua morte e invadido de culpa, quedou terrificado quando cercado por espíritos tenebrosos, agressivos e acusadores, e, próximo ao desespero total, foi salvo pela interferência de um anjo resplandecente, enviado por Deus para salvá-lo, e mostrar os castigos do Inferno. Tratava-se do seu anjo da guarda, e de pronto iniciaram a terrível viagem pelo vale das sombras das regiões infernais. Após terem presenciado as punições dos assassinos, assados em grelhas, viram a montanha dos grandes horrores e 
os tormentos dos espiões e traidores, e testemunharam a violência do que acontecia no vale da punição dos orgulhosos. Foi então que:

Depois de muito caminharem e de completarem a sua jornada tenebrosa, Tundal viu, não muito distante deles, uma besta incrivelmente grande e horrivel. De uma magnitude inacreditável, a besta excedia todas as montanhas que ele havia visto. Os olhos dela pareciam montes ardentes. A sua boca estava aberta e era tão larga que lheparecia capaz de conter nove mil homens armados. Nela, encontravam-se dois parasitas incomuns com suas cabeças viradas. Um deles, tinha sua cabeça postada contra a arcada dentária superior da besta $e$ os seus pés na arcada inferior; o outro,justamente o oposto, tinha sua cabeça voltada para baixo e seus pés voltados para cima na arcada superior. Eles eram quase como que colunas na boca da besta e a faziam parecer como se estivesse dividida em três portais. Chamas inextinguíveis eram expelidas da sua boca, que era dividida em três partes pelos três portais, e nessas chamas as almas condenadas eram compelidas a entrar. Um fedor insuportável também saia da sua boca. Não era nenhuma surpresa que a multidão que urrava e chorava no seu estômago era ouvida pela sua boca, visto que havia milhares de homens e mulheres sofrendo tormentos horriveis lá dentro.Havia, também, na frente da sua boca, uma multidão de espíritos de outro mundo que forçavam as almas a entrar. Antes que elas entrassem, eles as atacavam com muitos e diversos golpes. (GARDINER, $1989, p .159)^{13}$

Já Borges, no seu livro dos seres imaginários, acrescenta que: "No interior de Aqueronte há lágrimas, trevas, ranger de dentes, fogo, ardor intolerável, frio glacial, cães, ursos, leões e serpentes. Nessa lenda, o Inferno é um animal com outros animais dentro". (BORGES, 1996, p.111)

O interessante nessa metáfora corporal é o fato dela ser a imagem por excelência da boca do inferno medieval. A observação de Borges quanto à imagem literária de um animal dentro de outro, ao se referir a besta Aqueronte, alude aos ciclos míticos de devoração, ao mito de Jonas no ventre da baleia ${ }^{14}$, às gravuras dos grandes peixes

\footnotetext{
${ }^{13}$ As palavras em itálico são minhas. Mostram os termos relativos ao corpo/organismo (olhos, boca, cabeça, arcada dentária e estômago), à paisagem (montanhas e montes) e à arquitetura (colunas e portais), nas comparações alusivas à figura da besta chamada Aqueronte. Somente a palavra boca é mencionada seis vezes nesse curto trecho da visão.

14 Menciono o mito de Jonas dentro da baleia como uma imagem infernal por ter encontrado uma referência bastante clara a esse respeito num trecho do romance Moby Dick, de Herman Melville. O trecho consta do capítulo nove, intitulado de "O Sermão" e fala em versos "das costelas e dos terrores
} 
engolindo pequenos peixes, de Pieter Bruegel, e ao simbolismo da entrada da caverna iniciática. A metáfora se refere ainda a um tipo de conformação espacial e específica bastante similar ao que José Gil comenta no seu livro Metamorfoses do Corpo:

A imagem de um espaço em encaixe é de tal maneira pregnante que se pode enunciar uma lei geral da representação metafórica do corpo humano (na literatura,nomeadamente): são adequadas todas as imagens que representam o corpo por um espaço que possa conter o próprio corpo. Vemos assim proliferar as „fortalezas" os „castelos", os „,navios ", etc. Como corpos que contêm outros corpos. (GIL, 1997, p.160)

A Divina Comédia de Dante Alighieri, síntese notória das influências clássicas greco-romanas, especialmente o Virgilio da "Eneida", conforma muitas menções às correspondências entre o corpo e a paisagem, em termos de imagens literárias. Uma delas, que será examinada mais de perto é vinculada ao mito dos gigantes e consta do livro do Inferno, Canto XIV.

No terceiro giro do sétimo circulo, o areão ardente é atravessado por um riacho de águas vermelhas e ferventes, que corre entre margens de pedra, e sobre o qual a chuva de fogo é suprimida. Virgílio explica a Dante a origem dos rios infernais que é a mítica e alegórica figura do Velho de Creta (monte Ida), símbolo da humanidade; suas lágrimas vão formar no inferno o Aqueronte, o Estige, o Flegetonte e por fím, o Cócito. Está escrito no poema:

Há uma montanha lá que foi dileta De águas e frondes, e tem nome Ida, Agora abandonada e obsoleta.

Réa a escolhera então para guarida do infante seu; por próvido conselho sua manha com mais grito era escondida.

Ergue-se nesse monte um grande Velho, que pra Damiata tem voltado o dorso, e olha pra Roma como seu espelho.

Sua cabeça, de ouro, é um esplendor só; de pura prata os braços são e o peito, e de cobre é depois todo o seu torso.

dentro da baleia" e descreve a terrível visão da bocarra do grande monstro, como "as mandíbulas do inferno" que contém "intermináveis dores e tristezas". In MELVILLE, Herman. Moby Dick, England, Penguin Books, 1994, pp. 56-57. 
Daí pra baixo todo o resto é feito

de ferro, salvo que é de terracota,

sobre o qual mais se apóia o pé direito.

Cada parte, salvo a de ouro, é rota

por fendas de onde lágrimas gotejam

que, recolhidas, cavam essa grota.

No vale pelas fragas se despejam e o Aqueronte, o Estige e o Flegetonte, deste estreito canal então ensejam,

Até que lá, onde há o final desmonte, formam Cócito; e que lagoa é essa verás, pois não precisa que eu te conte.

Segundo a mitologia greco-romana, Réa, mulher de Saturno e mãe de Júpiter, esconde o seu filho recém-nascido no monte Ida, para que ele não seja devorado pelo pai, temeroso de uma profecia que dizia que um dos filhos iria destroná-lo. Seguindo essa tradição e com sua clara inclinação para a figuração humana, Dante atribuiu características humanas, as de um velho, ao monte Ida. Neste exemplo de correspondência corporal, tem-se uma iconografia de rica conotação simbólica, associada que está com a guarda do principal deus grego e com a origem dos rios infernais. As superposições de tempos e significados são muitas: ilha grega que tem montanha mítica que abriga um deus mitológico e que gera rios que fluem ao inferno cristão, mas o que chama mais atenção e que constitui o foco de interesse aqui, é a relação metafórica entre os elementos metais e minerais e o corpo do velho gigante. $\mathrm{Na}$ concepção de Dante, ele faz corresponder à cabeça do velho o elemento ouro; aos braços e ao peito, a prata; ao torso o cobre; as partes baixas o ferro; e aos pés a terracota. E não será esta ordem de elementos outra que não aquela da hierarquia dos metais da alquimia e do gnosticismo?

De fato, a obra de Dante é plena de simbolismos relativos à gnose, e, do ponto de vista filosófico, ela é especialmente eclética, ou seja, “(...) abraça e faz suas, sem discriminação, todas as correntes de pensamento, gnoseológicas, morais e religiosas, que a haviam precedido e que estavam vivas naquele tempo". (ALIGHIERI, 1998, p.8)

Além disso, Dante "põe no Limbo sem discriminação todas as correntes poéticas, filosóficas e científicas da idade clássica e do mundo árabe que tinham sido acolhidas pela cultura cristã medieval, tornando-as parte integrante desta". (ALIGHIERI, 1998, p.8) 
A hierarquia dos metais corresponde à hierarquia do corpo, sendo os pés, por sustentarem o corpo, os membros mais ligados à matéria pesada do mundo. Na medida em que se ascende no espaço corporal, vai ocorrendo uma progressiva depuração dos elementos químicos até a culminação no ouro, o mais nobre e puro dos metais, a grande obra da alquimia.

Este movimento para cima no corpo tem seu paralelo no simbolismo que associa os metais como os elementos planetários do mundo subterrâneo. Nesse caso, os metais representam energias cósmicas solidificadas e condensadas, com influências e atribuições diversas. A depuração dos metais simboliza a libertação das servidões carnais como dos influxos planetários nocivos.

O elemento mineral da metáfora corporal está vinculado ao simbolismo da montanha e do monte, que por serem altos, verticais e próximos do céu, significam a transcendência, a região do encontro do céu e da terra, a morada dos deuses e o objetivo da ascensão humana. Nessa mesma obra, no livro dedicado ao Purgatório, Dante localiza o paraíso terrestre no cume da montanha do Purgatório.

"O corpo da terra se assemelha ao dos animais, tecido pelas ramificações, as veias entrelaçadas entre si, constituídas pela nutrição e revitalização do planeta como uma de tantas criaturas”. (Da VINCI, 1950, pp. 413-414) Esta comparação foi feita por Leonardo Da Vinci, num de seus inúmeros escritos, ao buscar explicar de uma forma mais concreta e orgânica, o complexo processo da vida na terra, dentro de uma visão da ciência concernente à época do renascimento. Seu espírito investigativo e a impressionante paixão pela pesquisa o motivaram a estudar a natureza dos fenômenos da terra, do homem e dos animais em variados campos do conhecimento. A metáfora corporal mencionada alude aos seus estudos nos campos da geografia e da anatomia comparada, especialmente a dos animais.

Leonardo era o que se podia chamar de geólogo netuniano, visto a importância que ele dava à influência da água na vida da terra. Ainda mais se for considerado a sua tendência de estabelecer analogias entre o organismo humano e animal e os fluxos de água nos lagos, rios e oceanos. Existem diversos desenhos seus de paisagens, constantes na coleção real de Windsor, que mostram tempestades sobre vilas alpinas, vistas de montanhas com topos cobertos de neve, trajetos de rios como o vale do Arno, que ilustram o seu interesse pelo fenômeno do ciclo de evaporação, condensação e precipitação da água. 
No campo da anatomia comparada, onde é considerado um precursor, Leonardo concentrou esforços no estudo de várias espécies de animais no intuito de achar leis da organização dos seres vivos. Suas observações estendiam-se também ao estudo da botânica, com pesquisas sobre a estrutura e o desenvolvimento das plantas. Leonardo era propenso às bruscas mudanças de rumo nos estudos que fazia, dada a natureza essencialmente enciclopédica de sua mente e a sua inclinação ao tratamento fragmentário das questões científicas, além da vida intensamente atribulada que tinha. Os mais variados temas do conhecimento humano foram objeto de sua atenção, e não é de se admirar que ele, na transição entre a idade média e o renascimento, entre o pensamento enciclopédico escolástico e o rigor experimental do método científico emergente ${ }^{15}$, tenha elaborado correspondências simbólicas corporais relativas à alma da terra, em que figura uma metáfora do mundo feito carne:

Nada nasce onde não haja vida sensível, vegetativa e racional: as penas brotam nos pássaros e mudam de ano em ano; os pêlos brotam e mudam no corpo dos animais, salvo determinadas exceções, como os bigodes do leão, dos gatos e similares; a erva nos prados e as folhas nas arvores nascem e se renovam de ano em ano em quase todos. Podemos dizer que a Natureza tem uma alma vegetativa, que sua carne é o solo, seus ossos, as rochas, as rochas ordenadas em montanhas; seus tendões, os veios de tuba; seu sangue, as veias da água; o oceano, o lago de sangue que rodeia o coração; o fluxo e refluxo do mar, a respiração e a circulação do sangue pelos pulmões e os pulsos; o calor da alma do mundo, o fogo infundido na terra, residência da alma vegetativa que em diversos lugares exala em forma de águas termais, minas de enxofre ou vulcões como os de monte Gibello na Sicília e tantos outros. (Da VINCI, 1950, pp. 413-414)

O desenho de um acéfalo realizado por André Massom em 1936 se relacionava ao protótipo monstruoso que figurou na capa da revista Acéphale. Trata-se do corpo de um homem agigantado, de pernas e braços abertos, que parece se apoiar numa montanha às suas costas, pairando sobre uma paisagem de rochedos íngremes e ilhados e de um mar revolto pela fúria de uma ventania. O homem é representado sem a sua

\footnotetext{
${ }^{15}$ A atmosfera que se espalhava nas idéias e nas práticas científicas do Renascimento, bafejada por uma nova epistemologia, não estava de modo nenhum saturada de "cientificidade". De acordo com José Gil, "Tem-se antes a impressão que os primeiros caminhos da ciência se traçam numa tensão e numa amálgama permanente entre velhos ressurgimentos de um pensamento mágico e religioso, e a lógica própria à nova exigência de racionalidade e de experimentação". In Metamorfoses do Corpo, Relógio D“'Água Editores, Lisboa, 1997, p. 130.
} 
cabeça e brande na sua mão direita um coração em chamas, e na esquerda, um punhal. No seu ventre desenha-se o intestino num formato de espiral, simbolizando um labirinto, e no lugar dos genitais existe uma caveira.

Das possíveis interpretações que essa imagem oferece, a que mais interessa aqui é a correspondência simbólica do corpo humano com a paisagem, analogia que perdura até mesmo na modernidade. Isso se dá sobretudo a partir do surrealismo, que fez corresponder às diferentes partes do organismo humano um vasto conjunto de representações da natureza, segundo um sistema de imagens relacionadas e deformadas, próprio de uma certa mentalidade da era pós - industrial, hostil à idealização do corpo inteiro. Pois que o impulso da unificação dos seres do mundo e do cosmos, com centro no corpo do homem, que vigorava com maior intensidade no renascimento, foi progressivamente enfraquecido pelas divisões de modelos sucessivos e particularizados da ciência, só ganhando nova força com a síntese das formas convulsivas, característica das imagens do surrealismo. Esse movimento, liderado por André Breton, tinha como seu credo o "intercâmbio entre os diferentes reinos da natureza, ou entre o natural e o artificial, numa visão unitária que se funda sobre um princípio superior de equivalência entre todos os elementos da realidade múltipla". (MORAES, 2002, p.77) Esta tendência a dissolver os antagonismos, uma verdadeira anulação dos contrários, é a essência mesmo da imagem poética surrealista como um procedimento de "totalização do sentido". (MORAES, 2002, p.77) A razão de ser da poesia surrealista, segundo a ótica bretoniana, residiria "na preocupação de remontar à matéria original do mundo e da linguagem; na operação de transformar as substâncias do universo e do verbo; e no trabalho de interpretação através da grade inesgotável das analogias, chave de todo ato de decifração". (MORAES, 2002, p.77)

Ora, claro fica que são todos tópicos referentes aos postulados do conhecimento gnóstico e da alquimia. De fato, a representação reúne os quatro elementos água, fogo, terra e ar, que na maioria das tradições representam a essência das forças da natureza, sendo os meios da geração e da destruição das suas obras. "As operações da alquimia, da astrologia e das disciplinas esotéricas repousam na base desses valores universais"(CHEVALIER, 1998, p.362), e são eles que resumem uma ordem quaternária da natureza, temperamentos e etapas da vida humana.

O apreço pelo estudo do gnosticismo e das suas imagens, representou uma convergência de interesses tanto para Breton quanto para Bataille, e foi nessa base comum que se desenvolveu o gosto pelas imagens convulsivas e surrealistas, entre as 
quais o acéfalo em questão. Como a figura inaugural da capa da revista de Bataille e Masson, o acéfalo ${ }^{16}$ se prestou a representar uma ausência (a cabeça) que é, ao mesmo tempo, contraditória e plena de implicações. Significou não uma paródia, mas o contraposto do corpo canônico e idealizado inscrito no círculo e constante no tratado da pintura de Leonardo da Vinci, dando forma a um símbolo, proveniente do gnosticismo, de "desumanização" do homem. Continuou o processo de fragmentação das imagens do corpo, iniciado já no século XVI com o De Humani Corporis Fabricae de Vesalius. Nesse aspecto, Bataille defende uma inseparabilidade contraditória entre o corpo idealizado e o corpo concreto da matéria (banindo a cabeça da representação), que diverge da síntese "idealizada", não dualista e, portanto unitária, das imagens poéticas surrealistas. Diferenças à parte, o aspecto de retirada da cabeça, a sede da alma e símbolo do "alto" corpo, a parte nobre do homem, significa uma inversão das posições na hierarquia vertical do corpo cristão. O punhal, instrumento essencial dos sacrifícios, relaciona-se nitidamente com o coração, e dado o caráter mitológico da representação, faz lembrar os rituais de imolação dos astecas. Digo isso porque o coração em chamas pode muito bem simbolizar a tonalli, que significava o calor do sol, a energia fundamental na mitologia asteca. Inclusive, "a obra battailliana se organiza fundamentalmente a partir de uma nostalgia do ato sacrificial" (MORAES, 2002, p.52), conforme indica Eliane Moraes. Pois bem, "no mundo asteca é inegável que a extirpação do coração se converte no sacrifício humano paradigmático" (FEHER, 1992, 379), mas havia outras formas de execução como a decapitação e a cremação, em função dos sacrifícios terem sido cometidos em massa. De qualquer maneira, a imagem encontra ainda um paralelo nos horrorizados relatos dos colonizadores espanhóis, quando postos de frente a essas cerimônias, e que mencionavam corações queimados de índios.

O sentido geral das metáforas corporais circunscreve a orientação e a hierarquia dos espaços do corpo traduzidos pela relação entre a verticalidade e a horizontalidade (o alto e o baixo). Bataille observa que, passada a fase arborícola em que o homem vivia como os macacos:

(...) a vida terrestre se organiza basicamente em dois eixos: o horizontal, que orienta a posição da maior

\footnotetext{
${ }^{16}$ Conforme nos explica Eliane Moraes, "o acéfalo é um monstro arcaico, encontrado tanto em mitologias quanto em bestiários antigos. Bataille descobriu a imagem em meados dos anos 20 , quando trabalhava no Gabinete de Medalhas da Biblioteca Nacional de Paris, ao pesquisar figurações divinas em pedras trabalhadas pelos gnósticos nos séculos III e IV. A figura de um deus egípcio desprovido de cabeça - que mais tarde o autor identificaria à ,personificação acéfala do sol" - está portanto, na origem da concepção que, em 1936, aparece na revista dirigida por ele e por André Masson”. Moraes, Eliane Robert, $O$ Corpo Impossível, p. 183.
} 
parte dos animais, e o vertical, sob o qual se sustentam quase todos os vegetais. Somente o homem teria conseguido escapar de forma definitiva a essa regra. (MORAES, 2002, p.195)

Bataille prossegue escrevendo que "o ser humano pôde livrar-se da tranqüila horizontalidade animal, conseguindo apropriar-se da postura ereta dos vegetais e se deixando polarizar, em certo sentido, pelo céu" (MORAES, 2002, p.195). A postura ereta é digna e significa a imagem ideal do ser humano, que paira, esplendoroso, sobre a enorme confusão do mundo animal. Entretanto, o inexorável contrário dessa imagem é representado pelas partes baixas do corpo, que na sua abjeta realidade prendem o ser humano ao chão, impossibilitam sua ascensão ao céu, firmam sua condição de inferioridade terrena a qual é impossível evadir.

A correspondência com as plantas é significativa, pois elas crescem verticalmente como os seres humanos, têm a mesma dignidade do caule em pé e a baixeza das raízes, que de acordo com Bataille "fervilham sob a superfície do solo, repugnantes e nuas como vermes" (MORAES, 2002, p.196). A essa busca da luz e ânsia de ascensão ao espaço celeste próprias da fé do homem, e necessidade física essencial das plantas, corresponde o impulso contrário, também vital, da raiz ávida da podridão subterrânea e a manifestação do baixo corporal humano, bruto e preso a terra pelos seus pés. Dramática estruturação polarizada do espaço, envolve a verticalidade do subir e do descer, análoga a ascensão e queda do homem na simbologia gnóstica e cristã. Tanto é que Bataille, ao ilustrar o paralelo entre o alto e o baixo corporal do homem, cabeça e pés, e das plantas, flores e raízes, fala da polaridade do Céu e Inferno:

(...) a divisão do universo em inferno subterrâneo e em céu perfeitamente puro é uma concepção indelével, já que a lama e as trevas são os princípios do mal, assim como a luz e o espaço celeste são os princípios do bem: com os pés no barro e a cabeça mais próxima da luz, os homens imaginam obstinadamente um fluxo que os levaria para sempre a um espaço puro. (MORAES, 2002, p.196)

Persistente e vã esperança, marca registrada do comportamento secular humano, fica impossibilitada do movimento completo de ascensão, pois, diz Bataille, o "amplo movimento do solo em direção ao céu" 63 têm, como contrapartida inevitável, a "curta duração da vida”. (MORAES, 2002, p.199) 
Ao vincular o organismo humano com o vegetal, e contrapondo as sínteses idealistas do surrealismo de Breton, Bataille propõe uma renovada iconografia na ordem das correspondências simbólicas, referente ao corpo planta. $\mathrm{Na}$ sua concepção do antropomorfismo dilacerado as imagens resultantes da decomposição da figura humana engendram angustiantes poliformismos, e onde "o corpo é o suporte material sobre o qual as formas do conflito se inscrevem." (MORAES, 2002, p.199)

\section{AS MORADAS DO CORPO}

Nas correspondências simbólicas entre o corpo e a cidade, Dante sumariou no canto IX do Inferno a representação literária da cidadela maldita, na sua concepção do mundo inferior. Dite, a cidade da dor, capital do Inferno, cercada pelas torrentes lodacentas do Estige, é figurada como uma gigantesca fortaleza, murada de imensas e sólidas paredes negras de ferro, de mesquitas com minaretes rubros de brasa viva, e vigiada pelas terríveis fúrias mitológicas Megera, Tesífone e Aleto. É claro o débito para com a Eneida, de Virgílio, que no livro VI descreve a imensa fortaleza do Tártaro, como sendo "mais profunda que dois Olimpos superpostos; circundada por tríplice muralha” (BRANDÃO, 1993, p. 112), e na qual existe um enorme portão, preso por rígidas colunas de diamante que nem os deuses poderiam romper. Com a sua representação da cidade ardente Dite, Dante dá sequencia às urbes bíblicas incompletas e amaldiçoadas como Sodoma, Gomorra, Babel e a Grande Babilônia do Apocalipse, que simboliza a Roma demonizada na versão mítica cristã, personificada como a mãe das prostitutas. Consta no Apocalipse67:

E vi ali uma mulher montada num monstro rubro, com sete cabeças e dez chifres, coberta de palavras de blasfêmias. Revestida de púrpura e escarlate, a mulher estava adornada com ouro, pérolas e gemas preciosas. Tinha na mão uma taça dourada, com os resíduos impuros da sua fornicação. Na testa, um nome: A Grande Babilônia, mãe das prostitutas e das abominações do mundo. (APOCALÍPSE 17, 3-6)

Todas estas cidades infernais se alinham numa oposição patente àquelas das representações do Paraíso, como Heliópolis, a cidade do sol, Salém, a cidade da paz, e a Jerusalém Celeste, ou Nova Jerusalém, a cidade iluminada, feita de pedras preciosas e ouro, banhada pelo Rio da Água da Vida e que também consta do Apocalipse. Segundo 
Dubois, o itinerário que leva do Jardim do Éden (estado natural) à cidade terrena ${ }^{17}$ (estatuto social) significa, no seu aspecto negativo e dramático, a própria queda do homem, um processo de danação em que "A imagem da cidade é uma das que mais depressa se perverte, e gera monstros." (DUBOIS, 1995, p. 168)

A urbe medonha, de encarnação monstruosa, bem se mostra nos versos de Augusto dos Anjos:

Era como se, na alma da cidade,

Profundamente lúbrica e revolta,

Mostrando as carnes, uma besta solta

Soltasse o berro da animalidade. (ANJOS, 2001, p.102)

A cidade, como uma representação morfológica inscrita no espaço se agrega simbolicamente à figuração do corpo humano, aí assumindo um caráter de presença fantasmática, uma projeção imaginária que articula, além da movimentação corporal (ver, andar, compreender), um conjunto de signos crípticos: "A cidade é um texto a ser decifrado. Como corpo, a cidade é vivida; como figura, pode ser descrita; como texto é lida." (DUBOIS, 1995, p. 159)

Dubois fala ainda da dupla aderência do corpo humano e da cidade a imagística da Terra, que emerge no antropormofismo do vocabulário moderno enquanto "artérias", "circulação" urbana e "pulmão" verde das cidades, podendo-se metaforizar como a cidade carnal. Já Maffesoli, indica uma tendência da metáfora cidade-corpo na história da literatura: "De Joaquim de Flora a Schelling, de Santo Agostinho a Rimbaud, a cidade constitui a metáfora espacial da unidade corporal dos indivíduos. Em De civitate Dei, Santo Agostinho fala dessa harmonia interior formada por pedras vivas." (MAFFESOLI, pp. 57-59) Agostinho também fala, na terceira parte do livro, sobre a origem das duas cidades, a cidade de Deus e a cidade do Demônio.

Mas não é somente à cidade que se estende a representação do corpo humano. Anterior mesmo a urbe, o corpo já se expressa em termos da habitação: casa, templo ou túmulo da alma. Agrippa von Nettesheim ${ }^{18}$, na sua obra De occulta philosophia, diz que “Os antigos dividiam também os seus templos, edifícios públicos e outros edifícios de

\footnotetext{
${ }^{17}$ A cidade terrena simboliza, de acordo com Santo Agostinho, o amor próprio, egoísta, levado ao desprezo a Deus; a cidade celestial é, ao contrário, o desprezo a si próprio e o profundo amor a Deus. Cidade de Deus, Livro Décimo quarto, Capítulo XXVIII.

${ }^{18}$ Heinrich Cornelius Agrippa Von Nettesheim, nascido na Alemanha em 1486, falecido na França em 1534 ou 1535, foi médico, mágico, místico e alquimista, serviu ao Imperador Maximiliano I, e fundiu elementos neoplatonicos e da cabala na sua principal obra De occulta philosophia.
} 
acordo com a estrutura do corpo humano (...) tal como ele (Deus) deu à máquina do universo a simetria do corpo humano". (ROOB, 2001, p. 539)

Em termos mais concretos da orientação para o leste das igrejas da Idade Média, a razão se encontrava no fato de que a direção do norte, domínio do frio e da obscuridade era a predileta do Demônio, e, portanto, ao entrar-se na igreja, o norte ficava à esquerda, assim como o lado do corpo humano e do universo criado por Deus para o Demônio, o sinistru, no sentido mesmo da palavra latina que designa o direcionamento esquerdo.

No tocante as teorias das proporções que relacionam as medidas do corpo humano com as edificações, constam inúmeros exemplos dessas correspondências simbólicas. O modelo arquitetônico para as grandes catedrais góticas era o corpo místico de Cristo, o supremo arquétipo que emanava toda a natureza a partir de si, simbolizado pela projeção da planta em cruz. Na arte do século XX, do pintor espanhol Salvador Dali, existe um quadro de Gala, sua musa, transformando-se num projeto arquitetônico, que literaliza esta metáfora corporal, num experimento visual típico da justaposição surrealista. Na arquitetura modernista, tem-se o exemplo do Modulor de Le Corbusier, sendo sua referência uma atualização histórica dos cânones ocidentais, de relacionar as medidas do corpo humano as do edifício, constantes nas teorias arquitetônicas do romano Vitrúvio e do renascentista Alberti, citando apenas dois famosos eruditos que se ocuparam desse tipo de estudo.

Nas artes visuais constam numerosos exemplos de pinturas que relacionam o corpo com o habitat, como em algumas do artista flamengo Hieronimus Bosh, que figuram construções fantásticas, compósitos fabulosos do corpo humano com habitáculos, e iconografias híbridas da mulher-casa (Tentação de Santo Antônio, da Coleção SchmidtDegener, de Amsterdam), do homem-taberna (tríptico do Jardim das Delícias, Museu do Prado) e do homem-prostíbulo (Tentação de Santo Antônio, Museu Nacional de Arte Antiga, Lisboa).

Estas referências metafóricas ao corpo humano sugerem uma notável inclinação das sociedades ocidentais a projetar antropomorfismos nas suas representações do mundo, o que se confirma por José Gil, ao versar sobre as correspondências simbólicas, onde diz que "o homem não pode pensar sem fazer corresponder às coisas entre si (quer sejam símbolos, signos ou forças): é a própria condição da existência do seu corpo e do sentido imanente que este traz em si”. (GIL, 1997, p.116) 


\section{O CORPO FRAGMENTADO}

O corpo fragmentado, ou de partes isoladas, ou ainda mesmo em pedaços, práticamente inexiste nas representações do Inferno própriamente dito, até o século XIX visto que se pressupunha a manutenção da identidade terrena da alma danada, como requisito fundamental da didática da punição dos pecados, preconizada pelo clero. É interessante notar que a figuração do corpo despedaçado assumirá um conteúdo dramático e angustiante principalmente nas representações do canibalismo, fruto do contato com certas tribos do Novo Mundo recém-descoberto por Colombo ${ }^{19}$, e da anatomia médica renascentista, que ganha notório impulso a partir do século XV.

No tocante as figuras dos canibais, uma ilustração sem dúvida marcante e brotada de um imaginário medieval, consta na carta marinha publicada em 1525, em Estraburgo, e atribuída a Lorenz Fries. A xilogravura mostra canibais com cabeças de cão ${ }^{20}$ retalhando um corpo humano e o devorando. Seus pedaços estão dispostos numa trave como se fosse um açougue.

O canibalismo do Novo Mundo alude, curiosamente e em termos simbólicos, ao ritual da comunhão cristã, que conforme Michel Régis “(...) é o estágio supremo do canibalismo ocidental" (RÉGIS, p.120), na devoração ritualística do corpo de Cristo. ${ }^{21}$

No caso das práticas médicas renascentistas, as representações das dissecações de cadáveres se tornaram particularmente angustiantes devido ao fato dos anatomistas utilizarem corpos de criminosos recém-executados, na maioria das vezes pela forca. É de se salientar o medo que os condenados sentiam de que seus corpos fossem destinados à dissecação anatômica. Eles acreditavam que os corpos profanados e desfigurados não tinham esperança de serem recompostos no dia da ressurreição final, além de ser

\footnotetext{
${ }^{19}$ De acordo com Frank Lestringant, no seu livro sobre canibalismo, ao explicar a origem etimológica das representações de canibais, “(...) Colombo não é apenas o descobridor da América: ele é, antes de tudo, o inventor do canibal". LESTRINGANT, Frank, O Canibal: Grandeza e decadência, Editora da Universidade de Brasília, 1997, p.27.

${ }^{20}$ Ainda conforme Lestringant na obra citada, p. 28, a iconografia dos cabeças de cão correspondia aos povos fantásticos dos velhos acervos da Antiguidade, onde se denominavam de cinocéfalos, raça de homens monstruosos que se transmitiu de Plínio a Agostinho, e mais tarde aos Livros de etimologias de Isidoro de Sevilha.

${ }^{21}$ No citado artigo, Régis prossegue dizendo que "O cristão que comunga come o corpo do Filho (Cristo) que, de acordo com o texto evangélico, oferece a própria vida pela redenção da humanidade. Na transubstanciação cristã, o pão que aquele que comunga come é o próprio corpo de Cristo. Aqui, o pão significa o princípio efetivo de uma presença real. No sacrifício ritual do filho o Verbo (Deus) se faz carne (Cristo), conforme exige a metafísica ocidental do patriarcado". É interessante observar que o ritual da comunhão cristã é antagonizado pela devoração demoníaca por intermédio do simbolismo da boca do Inferno.
} 
especialmente repugnante para qualquer pessoa ver um cadáver despedaçado. As diversas maneiras históricas de se ver o corpo fragmentado não se esgotam aí.

Linda Nochlin (NOCHLIN, 1994) propõe, no seu livro O Corpo em Pedaços, duas categorias de representações que poderiam se chamar de modo idealizado nostálgico e modo positivista. No modo idealizado do fragmento corporal do séc.XVIII, nostálgico por princípio, a modernidade é figurada como uma irrevogável perda, um lamento pungente por uma totalidade perdida, um todo desaparecido. Um exemplo é o desenho de Henry Fuseli do "Artista Prostrado pela Grandeza das Ruínas Antigas". O modo positivista, revolucionário em essência, correspondente ao período moderno, e definido pelo evento transformador da revolução francesa, constituía o fragmento do corpo, no caso as cabeças guilhotinadas, como um tropo positivo mais do que negativo. O fragmento, para a Revolução e os seus artistas, antes de simbolizar uma nostalgia pelo passado, significava justamente a destruição desse passado, ou pelo menos a pulverização do que era percebido como repressivo nas suas tradições.

No final do século XIX e início do XX, o fragmento do corpo assume um sentido dramático e moderno na obra do escultor francês Auguste Rodin, mas de uma positividade latente, ao resumir na parte, a significação de um todo expressivo. Faz convergir os modos aparentemente inconciliáveis da nostalgia e o amor pela Antiguidade de um Fuseli (modo idealizado) com a positividade potencialmente destruidora dos anseios revolucionários franceses (modo positivista).

A acepção do fragmento que vale pelo todo fica evidente na descrição do processo criativo do escultor, feita por Bourdelle, onde ele atesta que, dizia Rodin: "A cabeça deste corpo? Esta preocupação não existe! Em meu trabalho a cabeça está em todos os lugares; faça todos os pedaços vivos! Se você souber onde está a vida das formas, o pensamento criará todas as partes ausentes”. (RODIN, 2001, p. 164)

Pois foi justamente fazendo pleno uso da vida das formas nos fragmentos animados de corpos convulsivos que Rodin concebeu a Porta do Inferno, sua obra maior. Sob marcante influência do afresco de Michelangelo (Juízo Final da Sistina) e da Divina Comédia de Dante (Rodin selecionou o Inferno da encomenda original que incluía o Purgatório e o Paraíso), a porta infernal de Rodin materializou a metáfora do corpo/porta e transpôs para o espaço da escultura a interpretação moderna do antro do Averno. A atmosfera ardente do Inferno se transformou num magma de bronze incrustado de corpos agônicos, imersos nesse mar de pecados sensuais e dor, onde a expressão corporal é a razão de ser da obra e o fragmento do corpo, num renovado 
modo de ver, adquire, na era da reprodução mecânica, e segundo a imaginação modular $^{22}$ de Rodin, um caráter de múltipla expressividade.

Nessa concepção do fragmento, qualquer parte do corpo pode manifestar sua própria beleza em um jogo permanente de substituição das imagens corporais. Não se passa da parte ao todo, mas de uma totalidade à outra, cada fragmento do corpo tendo seu próprio valor. O corpo resume na Porta o símbolo do Inferno e se impõe como a iconografia da passagem ao mundo maldito. A Porta é permanentemente fechada enquanto obra de arte física, mas no seu aspecto simbólico ela se abre sobre um mistério, além de ter "um valor dinâmico, psicológico; pois não somente indica uma passagem, mas convida a atravessá-la. É o convite à viagem rumo a um além..." (CHEVALIER, 1998, p.734)

O complexo de dinamismos que o regime das representações do corpo nas correspondências simbólicas costuma possuir, tem obviamente suas implicações no nível político e na ideologia, exemplarmente presentes na hierarquia da constituição e da postura corporal, onde:

A relação da cabeça com os pés, o cérebro e os órgãos sexuais, da boca e do ânus é comumente tratada como expressando relevantes padrões de hierarquia... o mesmo impulso que busca harmonizar a relação das experiências físicas e sociais deve afetar a ideologia. Consequentemente, uma vez que a correspondência entre os controles corporais e sociais é constatada, as bases estarão lançadas para considerar a correlação das atitudes no pensamento político e na teologia. (HANAFI, 2000, p. 241)

A primordialidade do corpo na existência humana é de tal ordem que, de acordo com a coincidência do pensamento de alguns filósofos, como Descartes e Hobbes, "A filosofia do homem começa com as bases fisiológicas da percepção e estende-se às formas da organização social" (HANAFI, 2000, p. 135). Não é de se estranhar portanto, o farto uso das correspondências simbólicas e das metáforas corporais nas representações históricas do imaginário ocidental. Ao se mencionar a importância do corpo na sua qualidade ancestral, se torna oportuno lembrar o longo processo evolutivo por meio do qual o ser humano assumiu uma postura ereta. E constatar que a posição

\footnotetext{
${ }^{22}$ Quero dizer com isso que Rodin utilizou, algumas vezes, de várias versões do mesmo modelo para compor o espaço da Porta. Sobre a questão dos múltiplos na obra de Rodin, sugiro a leitura dos capítulos The Originality of the Avant-Garde e Sincerely Yours do livro The Originality of the Avant-Garde and Other Modernist Myths, London,The MIT Press, 1988, de autoria de Rosalind E. Krauss.
} 
vertical tem claras implicações culturais além dos seus aspectos biológicos. A tensão resultante desse encontro entre as tendências civilizadas e as animais no espírito humano, quase nunca equilibradas, mas quase sempre alternadas, parece ser determinante no destino das sociedades no mundo. Mas essa inclinação à dissolução e à dispersão do corpo do antropomorfismo dilacerado, pode ter encontrado um nicho idealizante no anseio do homem contemporâneo em extravasar os limites da sua existência corporal. Falo aqui do corpo ciborgue que indica ser o futuro da carne.

No seu discurso da motricidade, João Batista Freire explica que os limites corporais do homem foram largamente superados pelas extensões corporais criadas pela cultura humana (FREIRE, 1991). A roda, o carro, o avião, as máquinas e os instrumentos das mais variadas finalidades, e recentemente, a tecnologia computacional, estenderam em muito a capacidade humana em inúmeras atividades físicas e intelectuais. A intensa dedicação em superar os limites naturais da corporeidade humana traduz um anseio de imortalidade, de expansão do ego e de preenchimento de um vazio existencial, que caracteriza uma parcela significativa das sociedades do mundo industrializado ocidental. Ainda de acordo com Freire "A cultura humana é, de uma certa forma, a extensão cada vez mais ampla do corpo humano. O corpo que não seria humano não fosse a cultura" (FREIRE, 1991, p.40). *E o que está por detrás de todo este impulso de expansão do ego e de vontade de absorver conhecimento senão uma atualização da antiga sedução demoníaca de se igualar à condição divina feita aos primeiros pais, Adão e Eva?

Simbolicamente falando na versão do mito cristão, o veneno demoníaco da tentação do fruto proibido da árvore do Éden, espalhado na consciência do homem, originou o paulatino processo histórico de individualização, característico das sociedades modernas do mundo desenvolvido, e que se notabiliza por um intenso egocentrismo e um extremado narcisismo (não foi o orgulho, na versão agostiniana, o motivo principal da queda do Demônio?).

$\mathrm{Na}$ ânsia de mimetizar o divino, o imaginário ocidental produziu uma renovação no mito do corpo mecânico. Autômato e Robô, num primeiro momento (século XVIII XIX) e numa visão mecanicista newtoniana, passou-se ao sistema de integração da carne com a mecânica (biomecânica, no século XX), já numa ótica da complexidade científica, figurando-se o andróide e o ciborgue, e em 1990 foi produzido o primeiro bióide (ser vivo com desenho artificial, a ovelha Dolly). Atualmente, conforme argumenta o físico Luiz Alberto Oliveira, "estamos a caminho de poder redesenhar a 
forma humana" (NOVAES, 2003, p. 168). Oliveira prossegue dizendo que "a perspectiva então é a de que nosso devir, nosso futuro, seja nos tornarmos borgues, híbridos de células e chips." (NOVAES, 2003, p. 169)

E isso numa perspectiva substancialista em que o corpo se apresenta materialmente, mantendo uma singularidade identitária, de indivíduo, sem falar nas integrações cibernéticas da mente com o computador na chamada inteligência artificial.

Uma interessante abordagem da metáfora corporal é feita por Manuel Caldas (CALDAS, 1987) na sua análise do regime da figura deformada nas pinturas da fase surrealista de Picasso (1925-1932), os seus chamados "monstros", onde a relação da figura e do espaço se define na distinção entre o conceito de corpo e o de organismo, que é feita nos seguintes termos: "o organismo existe no espaço, o corpo é um espaço. A soberania do óptico impõe a distância de representação ao corpo, situando-o no espaço, organizando-o na imagem do corpo próprio, do organismo". (CALDAS, 1987, p.68) Mas a realidade do olhar não é somente a realidade do ótico. Manuel desenvolve o argumento dizendo que "se o espaço se constitui pela via do corpo, ele constitui-se não em forma, mas em formação, espacialização de si mesmo, segundo afetos e relações de afetos". (CALDAS, 1987, p.68)

A essa espacialização chama José Gil uma „modelagem “ do espaço pelo próprio corpo: "Já não é uma coisa que é modelada no espaço, mas o espaço que é modelado por 'uma coisa' (o corpo)". (CALDAS, 1987, p.69) No caso das monstruosidades de Picasso, as figuras se apresentam como formadoras e protagonistas dos seus próprios espaços, até onde se estendem as suas deformações, e aí operam uma espacialização, tornam-se elas mesmas um espaço (espaço dentro de outro espaço ou regime espacial dentro de um outro regime espacial, nas ocasiões em que há um contraste figuradeformada/fundo-cenário). O corpo torna-se então a metáfora do espaço.

Nas contorções agônicas de dor após a sua queda no fundo do poço do Inferno, no centro da terra, pode-se dizer que o corpo do Demônio gigante dantesco, semelhante ao que acontece aos monstros de Picasso, "sai de si mesmo, inunda o espaço circundante, integra esse espaço nele, agita-se num excesso que rompe com a definição do 'corpo clássico' e com a sua individualidade" (CALDAS, 1987, p.69), que ele possuía quando habitava a esfera do Paraíso Divino, bem como com a sua "delimitação rigorosa, acabamento e contensão" (CALDAS, 1987, p.69). É um tema ligado, antes, à tradição do corpo grotesco, o corpo que Bakhtin (BAKHTIN, 1996) diz ultrapassar a si 
próprio, atravessar os seus próprios limites. A ênfase é posta nas partes do corpo onde este ora se abre ao mundo exterior, isto é, onde o mundo penetra nele ou sai dele, ora se lança ele próprio no mundo, nos orifícios, nas protuberâncias, em todas as ramificações e excrescências: boca aberta, órgãos genitais, falo, seios, barriga grande, nariz.

Bakhtin chama atenção para o que ele denomina de dualidade existente entre o corpo grotesco e o corpo canônico, na sua análise da obra de Rabelais. De fato, as características do corpo grotesco popular são cósmicas e universais, é um corpo de superfície aberta (orifícios) e contínua (se funde com outros corpos). Suas representações típicas são o nariz (falo), a boca, o ventre e os órgãos genitais (frontais e posteriores). Suas excrescências e orifícios ultrapassam as fronteiras entre dois corpos e entre o corpo e o mundo. É o corpo grotesco por excelência que tão bem se ajusta às representações históricas do demônio e dos seus consortes, além dos condenados do inferno.

Em oposição tem-se o corpo canônico, perfeitamente pronto, acabado, rigorosamente delimitado, fechado, mostrado do exterior, sem mistura, individual e expressivo. Sua superfície é fechada e individualizada (não se funde com outros corpos). Sendo um único corpo não conserva nenhuma marca de dualidade. É o corpo místico do Cristo Rei feito à imagem e semelhança do Deus Pai. As suas partes representativas são a cabeça, os olhos, as orelhas, os braços, as pernas, as mãos e os pés.

O corpo grotesco representa a garantia de continuidade do mundo e de uma transformação vital e reprodutora da vida, pois nele a morte de um corpo engendra o princípio orgânico da vida de um outro, enquanto que no corpo canônico o estatuto vigente é o da separação e o da esterilidade.

O limite da condição corporal humana é que define o indivíduo numa sociedade, e a relação do seu corpo e a sua identidade é comentada por David Le Breton:

Nas culturas ocidentais, o corpo humano está fundado num fechamento da carne sobre ela mesma e sobre a humanidade intrínseca e única dessa matéria que traça para o homem seu rosto e sua forma. A separação que distingue o indivíduo de um outro é rigorosa; o corpo de um homem não poderia se misturar estruturalmente ao de um outro. O corpo é o vetor da individualização, ele estabelece a fronteira da identidade pessoal; confundir essa ordem simbólica que fixa a posição precisa de cada individuo no tecido social significa apagar os limites identificadores do fora e do dentro, do eu e do outro; essa confusão coloca radicalmente em questão a afirmação de si e faz duvidar sobre a 
natureza do outro. A igualdade do homem consigo mesmo, a identidade de si, implica a igualdade com seu corpo. A condição do homem é corporal. Subtrair-lhe alguma coisa, ou lhe acrescentar, coloca esse homem em posição ambígua, intermediária. (LE BRETON, 1995, p. 64)

Le Breton centra seu ensaio na discussão da dispersão corporal decorrente dos transplantes de órgãos e o seu impacto na bioética. Entretanto, o que mais interessa aqui, é a confusão da ordem simbólica identificadora dos indivíduos na sociedade, condição demoníaca que tem por pressuposto introduzir a incoerência no mundo. Nesse sentido, volta-se a questão do corpo grotesco e carnavalesco de Bahktin, da mistura dos corpos (a inserção de um corpo no outro), garantindo sua continuidade e a manutenção da vida. O impulso sexual e a desordem do mundo são características da pândega demoníaca, que termina por identificar-se com os processos de reprodução, transformação, inserção, partilhamento e manutenção dos corpos e organismos. A tendência demoníaca grotesca e carnavalesca é a da balbúrdia transformadora que despreza o nível individual, pois é um processo eminentemente coletivo.

Num outro ensaio de sua autoria, intitulado Adeus ao Corpo, Le Breton dá continuidade à discussão da fronteira identitária corporal, desta vez abordando as questões relativas à tecnologia eletrônica computacional e a inteligência artificial, como recrudescimentos doimaginário milenarista de abandono e desprezo do corpo físico. A meta gnóstica da ascensão espiritual, que antes se dava pelo conhecimento e procedimento mágico, se realiza agora, na fusão da consciência individual com o sistema de computadores integrados, no chamado ciberespaço, onde "o corpo eletrônico atinge a perfeição, imune à doença, à morte, à deficiência física"98. Como um anjo, ou como um demônio, o novo corpo, sem a espessura da carne, flutua, numa atmosfera eletrônica de dados, que compõe o universo computacional. Novamente aqui, ocorre uma confluência com o corpo grotesco de Bahktin, desta feita no aspecto da sua superfície aberta e da sua fusão ao mundo. A dissolução corporal no ciberespaço (e a consequente formação de um corpo informático globalizado) é a mesma do entranhamento do indivíduo na orgia coletiva do corpo carnavalesco e grotesco. As características cósmicas e universais em ambos são as mesmas.

\section{REFERÊNCIAS BIBLIOGRÁFICAS}

ALIGHIERI, Dante. A Divina Comédia. São Paulo: Editora 34, 1998. 
ANJOS, Augusto dos. Eu e Outras Poesias. Rio de Janeiro: BCD União de Editoras, 2001.

BAHKTIN, Mikhail. A Cultura Popular na Idade Média e no Renascimento: $O$ Contexto de François Rabelais. Brasília: Universidadede de Brasília, 1996.

Bíblia Sagrada. Rio de Janeiro: Barsa, 1965.

BORGES, Jorge Luis. O Livro dos Seres Imaginários. São Paulo: Globo, 1996.

BRANDÃO, Junito. Dicionário Mítico-Etimológico: Mitologia e Religião Romana. Petrópolis: Vozes, 1993.

BROWN, Peter. The Body and Society. New York: Colubia University Press, 1988.

BRUNEL, Pierre. Dicionário de Mitos Literários. Rio de Janeiro: José Olympio, 1998.

CALDAS, Manuel de Castro. A Figura e o Corpo. Portugal: Imprensa Nacional, Casa da Moeda, 1987.

CASSIRER, Ernst. Indivíduos e Cosmos na Filosofia do Renascimento. São Paulo: Martins Fontes, 2001.

CHEVALIER, Jean. Dicionário dos Símbolos. Rio de Janeiro: José Olympio, 1998.

CLARK, Kenneth. O Nu: Um Estudo sobre o Ideal em Arte. Lisboa: Editora Ulissea.

COUSTÉ, Alberto. Biografia do Diabo. Rio de Janeiro: Rosa dos Tempos, 1996.

DA VINCI, Leonardo. Tratado de La Pintura. Madrid: Aguilar, 1950.

DUBOIS, Claude-Gilbert. O Imaginário da Renascença. Brasília: Universidade de Brasília, 1995.

FEHER, Michel. Fragmentos para una Historia del Cuerpo Humano. Madrid: Taurus Ediciones, 1992.

FERRO, Sergio. Michelangelo, Notas por Sergio Ferro. São Paulo: Palavra e Imagem, 1981.

FONTANELLA, Francisco Cock. O Corpo no Limiar da Subjetividade. Piracicaba: Universidade Metodista de Piracicaba, 1995.

FREIRE, João Batista. De corpo e Alma: O discurso da motricidade. São Paulo: Ed. Summus, 1991.

GARDINER, Eileen. Visions of Heaven \& Hell Before Dante. New York: Italica Press, 1989.

GIL, José. Metamorfoses do Corpo. Lisboa: Relógio D'água, 1997.

HANAFI, Zakiya. The Monster in the Machine. USA: Duke University Press, 2000.

LE BRETON, David. “A Síndrome de Frankstein.” In: Políticas do Corpo, por Denise Bernuzzi de SANT'ANNA. São Paulo: Estação Liberdade, 1995. 
MAFFESOLI, Michel. "A Conquista do Presente."

MORAES, Eliane Robert. O Corpo Impossível. São Paulo: Editora Iluminuras, 2002.

NOCHLIN, Linda. The Body in Pieces: the fragment as a metaphor of modernity. New York: Thames \& Hudson, 1994.

NOVAES, Adauto. O Olhar. São Paulo: Schwarcz, 1997.

RÉGIS, Michel. “A Síndrome de Saturno ou a Lei do Pai: máquinas canibais de modernidade." Catálogo da XXIV Bienal Internacional de São Paulo. São Paulo. 120.

RODIN, Auguste. Auguste Rodin: A Porta do Inferno. São Paulo: Pinacoteca do Estado de São Paulo, 2001.

ROOB, Alexander. Alquimia e Misticismo. Köln: Taschen, 2001.

SCMITT, Jean-Claude, e Jacques LE GOFF. Dicionário Temático do Ocidente Medieval. Bauru: Universidade do Sagrado Coração, 2002. 